\title{
Mobile Health Monitoring System
}

\author{
S. Pothumani, K.Anita Davamani, C.Anuradha, N.Priya
}

\begin{abstract}
Now-a-days in-health has become the leading cause of death in worldwide. It has become very hard to find the health conditions in the patients by the medical practitioner as it needs an experience and knowledge about the disease they are dealing with. The diseases can be affected in many parts of the patient's body. They are many kinds of places in the human body where the different kinds of health problems is affected with; some are cancer, fever, skin problems, disabilities, infections, inner body diseases, outer body diseases, etc.,. In the era of rapid revolution of Internet of Things (IoT), the sensors for monitoring the patients is every way of feeling their each module of visibility of the things which the world is affected for it and their working of the medicine is created through this development of the Internet of Things for the healthcare centers in worldwide. This paper will be explaining about the architecture for the tool used to monitor the patient's critical levels and algorithms used for monitoring the patient's health and resolving the problems for the problems they are suffering for. I will be also explaining the other parameters used in the monitoring of things in which shows the activities of human health condition. The algorithm is also used to predict the next symptom of the disease and know it soon by the sensor which tells a sure about the symptom which the host is been affected with and will be seen and cured with help of the cloud data in which the whole information Is been stored about the disease and cure for it which is linked to the single cloud which the information is collected and resolving the problems the problems they have been suffering for it.
\end{abstract}

Keywords Internet of Things, healthcare, Machine Learning, Depth First search algorithm, cloud storage.

\section{INTRODUCTION}

The Internet of Things (IoT) refers to a particular notion of the capacity of network appliances to detect and retrieve information from the globe around us and then exchange information over the Internet where it can be handled and used for different interesting uses. Predictions of the Internet of Things ' effect on the Internet and the economy are noteworthy, with some expecting up to 100 billion phones. Internet of Things for in healthcare activities are being developed for years and years for health activities where it performs a significant role in the monitoring of the some in-health activities which the devices are connected to the Internet have been hosted to patients in various forms.

Revised Manuscript Received on July 22, 2019

S.Pothumani, Department of CSE, Bharath Institute of Higher Education and Research, Chennai, Tamilnadu, India

K.Anita Davamani, Department of CSE, Bharath Institute of Higher Education and Research, Chennai, Tamilnadu, India.

C.Anuradha, Department of CSE, Bharath Institute of Higher Education and Research, Chennai, Tamilnadu, India.

N.Priya, Department of CSE, Bharath Institute of Higher Education and Research, Chennai, India
Whether the data comes from connected devices of various real time instruments through which the some of the things are undertaken for it like, blood pressure, electro cardiogram, temperature, Blood sugar levels, regular in-health information, and treatment analysis for different treatment for different types of health problems. Many of these measures need a follow-up by the health care professionals. The data always goes to remote cloud for easy identification of the disease who are affected with, many type of analysis report of each and every disease (symptoms, medications, etc.,.) are produced on the cloud and it sends the relevant results to healthcare personnel or center's by using mobile phone or any other active devices which are connected to the hardware.

An enormous healthcare data generated by the Internet of Things (IoT) are considered of high business value. Data mining algorithms can be applied to Internet of Things to expose unknown information from these data containing the reports and data of the diseases which it deals with. Using the different methods of solving the problem through the knowledge of computer software's where each and every person can be taken forward with their own solutions in the hard times of it. Government or respective authorities may use this analysis and can take the further step to cure or prevention for the disease. In this paper, I will be explaining the process of data collection, necessary tools and methods for using these data for data analysis. For this instance, the virtual data for the disease will be stored which contain only few number of disease information in it, where it began to do the needs for it. By using this data or there may be a collection of previous data of in-health patients and were we can find our report and symptoms of the patient and the cause for being in-health problems as soon as possible. This paper creates a cause for the affected patients in worldwide. The present situation of the world for the affected patients are unpredictable so as the data of the every affected patient's is gathered and being stored the data in cloud and we are going to have a mixture report of all the affected patients and find the symptoms of the affected patients and are ready to use it. This creates a possibility of removing the disease from the body or curing the disease (if it is not removable) for the future belief of the patients. The device is made for monitoring

thehumanhealthparameters.Someofthedevicesusedintherece nttrendsforthehealthmonitoringarefit-bits,smart watches, smart bands, etc. These devices are being only used by the $30 \%$ of the world for the cost of it which some of them cannot afford to buy these devices. The health is being a very big problem to the human race

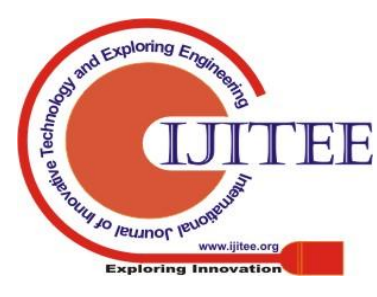


where the infecting disease are more and medicines for them became less for the cure of it. So, the big step for the forward to the creation of the modern days is defined unsuccessful for the world because of the health issues which causes the early deaths in the world. This is the whole lot of theory for introducing my project.

\section{RELATED WORK}

Nancy Fernando E, Rojashree,
DelshiHowsalyadeviproposed a patient monitoring is crucial for the environment of extensive and critical care in operation and emergency care. Android has recently become one of the most common medical technology used. The paper's objective is to address the android-based patient surveillance system study to provide individuals in a more economical way with better healthcare. This article also discusses the comparison of the arts solution sets accessible for emergency alarm generation in health care surveillance devices and technology.

Mirjana Maksimovic; Vladimir Vujovic; BrankoPerisichas given a percpective about health is that, Health is the basic ability that human beings need to interpret, think, and behave efficiently, and thus it is a main component in the growth of the person, but also of the human environment. It is therefore essential to provide adequate means of ensuring adequate healthcare service depending on the surveillance of parameters and the immediate provision of medical help. The design and execution of fresh techniques, particularly the Internet and Wireless Sensor Networks (WSNs), widely recognized as the Internet of Things, allows for a worldwide attitude to the growth of health care system infrastructure. This contributes to an e-health scheme that provides all stakeholders with useful data, regardless of their present place, in real time. A Do-It-Yourself (DIY) option for sustainable and adaptable patient-oriented infrastructure growth is provided in this article, depending on well-known low-cost techniques.

Iazul Islam ; DaehanKwak ; Md.humaunkabirMahmudhossain Kyung-supkwank made the Internet of Things (IoT) the main construction blocks in the growth of pervasive cyber-physical intelligent frameworks. The Internet of Things has a range of fields of implementation including healthcare. The revolution in the Internet of Things is redesigning modern healthcare with successful technological, financial and cultural outlooks. This paper surveys advances in Internet of Things-based healthcare technologies and reviews the state-of - the-art network architectures / platforms, applications, and industrial trends in Internet of Things-based healthcare solutions. Moreover, this article analyzes separate safety and privacy characteristics of the Internet of Things, including safety criteria, risk models, and from a healthcare viewpoint assault taxonomies. Furthermore, this article offers an smart cooperative safety model to minimize security risk ; describes how distinct technologies such as big data, environmental intelligence and wearable can be leveraged in the framework of healthcare ; covers distinct Internet of Things and e-Health policies and laws worldwide Identify how economies and communities can be facilitated with regard to sustainable development ; and provide some possibilities for future studies on the Internet of Things-Based Healthcare oriented on a number of accessible problems and challenges.

In the present scenario the cases are being like this that the IOT is becoming advanced to the technology in other countries and continents. But, the technology in healthcare is being driven into this situation. Before times, people were visiting hospitals for cure but now-a-days people are using smart technologies for the check-up and cure. For this the Internet of Things is being evaluated for the future scope of the healthcare. The Internet of Things is been creating technologies for every field in this world but we are going to talk about the healthcare technology. For healthcare we have created many technologies like smart watches, smart bands, fit-bits, some of the applications like Google fit are creating technology for better living in the world. These gadgets are being used since past years, everyone in our country about $30 \%-40 \%$ of the people used these technology in this country. Advantages of these gadgets are best look, lightweight, very easy to handle, it is smart. Disadvantages are these don't have long life, its battery backup is not so good, and the batteries used in this are not good to use it causes heat. These are the technologies being used in the present case scenario also; we have explained the disadvantages and advantages of the health caretechnology.

\section{PROPOSED SYSTEM}

Now let's talk about the proposed technology. This is a project on IOT in-healthcare; this will be giving the data of the patient's health standards and role of body metabolism to the screen nearby the operation theatre in the hospital. The hardware contains the body sensor in the miniature way, the hardware works on the proposed way of building it. The hardware will be made with the help of the finger ring or any method of using it, in this ring the components have some parts like body sensor and a Bluetooth module, it powers with the battery cell or with solar power.. First the client has the access to the hardware through which the sensor scans the body by the wish of the patient. After the scanning process the device will be getting the information through the saved list of symptoms and diseases, by which it gets the information from it. The offline resource is nothing but thedatabase.Second, the database is accessed and the information will be sent to the patient or the doctor of that patient by which the doctor gets an idea about and sends the report with the prescribed medications for it to thepatient.Third, the notified reports and the prescription which were given by the doctor to the patient is given to the nearest chemist or pharmacy for getting the required medicines given by the doctor. The client turns off the device and uses it whenever they feel to be used. 


\section{SYSTEM ARCHITECTURE}

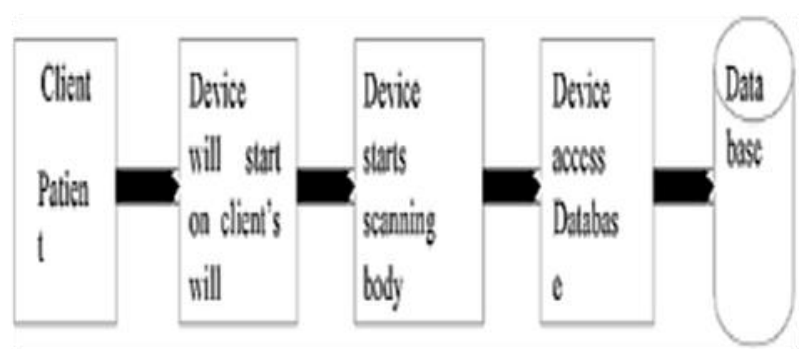

Fig 1 client to database

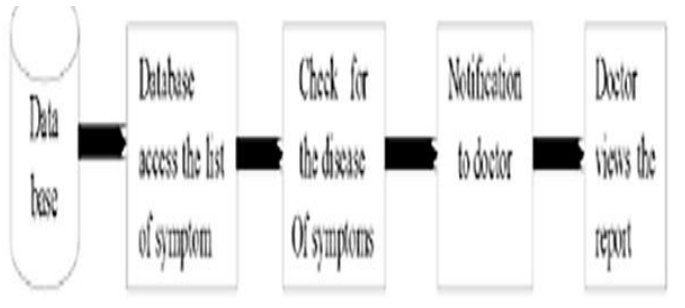

Fig 1 database to doctor

\section{SYSTEM IMPLEMENTATION}

This system is implemented by using pulse sensor, thermal sensor, connecting board, Wi-fi or Bluetooth module as hardware and Adruino kit, Interface tool and Android kit. It is used by any small clinic medicalpractitioner.It reduces the patient queue in clinics orhospitals.It is used by the patient also by wearing it as healthband. In this, we are using Breadth-first search (BFS) algorithm used for tree or graph data structures traversing or searching. It starts from root, explores the neighbors first then to others. This algorithm is used for better recognition of the problems which requests for it. This program search for the problem related tree of it.

\section{RESULT ANALYSIS}

The hardware connects with the nearby devices to the screen in the room. The devicemay be heavy to be believed but it will be good while using. We can also access it in a distance while it carried with the army officials; It helps while in the war time by giving the information of the each battalion of the force which helps to decide with the person change. The advantages of this hardware maybe little but useful for the country while upgrading to the futureneeds.

\section{CONCLUSION}

This paper dealsthe present healthcare systems. This contains whole description of the product and the working of the product will be explained in the report. This report will be a big record for the healthcare system that to may be for a person or a company. This concludes the whole thing about the project being explained in this report data. These projects may be a success for the present technology culture in the country, by this project there will be equivalent importance to all the people who are in this country. By which there will be decrease in the death rate in the country which is affected by disease which are evolved in thecountry.

\section{REFERENCES}

[1] Kumaravel A., Rangarajan K.,Algorithm for automaton specification for exploring dynamic labyrinths,Indian Journal of Science and Technology,V-6,I-SUPPL5,PP-4554-4559,Y-2013

[2] P. Kavitha, S. Prabakaran "A Novel Hybrid Segmentation Method with Particle Swarm Optimization and Fuzzy C-Mean Based On Partitioning the Image for Detecting Lung Cancer" International Journal of Engineering and Advanced Technology (IJEAT) ISSN: 2249-8958, Volume-8 Issue-5, June 2019

[3] Kumaravel A., Meetei O.N.,An application of non-uniform cellular automata for efficient cryptography,2013 IEEE Conference on Information and Communication Technologies, ICT 2013,V-,I-,PP-1200-1205,Y-2013

[4] Kumarave A., Rangarajan K.,Routing alogrithm over semi-regular tessellations,2013 IEEE Conference on Information and Communication Technologies, ICT 2013,V-,I-,PP-1180-1184,Y-2013

[5] P. Kavitha, S. Prabakaran "Designing a Feature Vector for Statistical Texture Analysis of Brain Tumor" International Journal of Engineering and Advanced Technology (IJEAT) ISSN: 2249-8958, Volume-8 Issue-5, June 2019

[6] Dutta P., Kumaravel A.,A novel approach to trust based identification of leaders in social networks,Indian Journal of Science and Technology,V-9,I-10,PP--,Y-2016

[7] Kumaravel A., Dutta P.,Application of Pca for context selection for collaborative filtering,Middle - East Journal of Scientific Research,V-20,I-1,PP-88-93,Y-2014

[8] Kumaravel A., Rangarajan K.,Constructing an automaton for exploring dynamic labyrinths,2012 International Conference on Radar, Communication and Computing, ICRCC 2012,V-,I-,PP-161-165,Y-2012

[9] P. Kavitha, S. Prabakaran "Adaptive Bilateral Filter for Multi-Resolution in Brain Tumor Recognition" International Journal of Innovative Technology and Exploring Engineering (IJITEE) ISSN: 2278-3075, Volume-8 Issue-8 June, 2019

[10] Kumaravel A.,Comparison of two multi-classification approaches for detecting network attacks, World Applied Sciences Journal,V-27,I-11,PP-1461-1465,Y-2013

[11] Tariq J., Kumaravel A.,Construction of cellular automata over hexagonal and triangular tessellations for path planning of multi-robots,2016 IEEE International Conference on Computational Intelligence and Computing Research, ICCIC 2016,V-,I-,PP--,Y-2017

[12] Sudha M., Kumaravel A.,Analysis and measurement of wave guides using poisson method,Indonesian Journal of Electrical Engineering and Computer Science,V-8,I-2,PP-546-548,Y-2017

[13] Ayyappan G., Nalini C., Kumaravel A., Various approaches of knowledge transfer in academic social network,International Journal of Engineering and Technology,V-,I-,PP-2791-2794,Y-2017

[14] Kaliyamurthie, K.P., Sivaraman, K., Ramesh, S. Imposing patient data privacy in wireless medical sensor networks through homomorphic cryptosystems 2016, Journal of Chemical and Pharmaceutical Sciences 92.

[15] Kaliyamurthie, K.P., Balasubramanian, P.C. An approach to multi secure to historical malformed documents using integer ripple transfiguration 2016 Journal of Chemical and Pharmaceutical Sciences 9

[16] A.Sangeetha,C.Nalini,"Semantic Ranking based on keywords extractions in the web", International Journal of Engineering \& Technology, 7 (2.6) (2018) 290-292

[17] S.V.GayathiriDevi,C.Nalini,N.Kumar,"An efficient software verification using multi-layered software verification tool "International Journal of Engineering \& Technology, 7(2.21)2018 454-457

[18] C.Nalini,ShwtambariKharabe,"A Comparative Study On Different Techniques Used For Finger - Vein Authentication", International Journal Of Pure And Applied Mathematics, Volume 116 No. 8 2017, 327-333, Issn: 1314-3395

[19] M.S. Vivekanandan and Dr. C. Rajabhushanam, "Enabling Privacy Protection and Content Assurance in Geo-Social Networks", International Journal of Innovative Research in Management, Engineering and Technology, Vol 3, Issue 4, pp. 49-55, April 2018.

[20] Dr. C. Rajabhushanam, V. Karthik, and G. Vivek, "Elasticity in Cloud Computing", International Journal of Innovative Research in Management, Engineering and Technology, Vol 3, Issue 4, pp. 104-111, April 2018.

[21] K. Rangaswamy and Dr. C. Rajabhushanamc, "CCN-Based Congestion Control Mechanism In 
Dynamic Networks", International Journal of Innovative Research in Management, Engineering and Technology, Vol 3, Issue 4, pp. 117-119, April 2018.

[22] Kavitha, R., Nedunchelian, R., "Domain-specific Search engine optimization using healthcare ontology and a neural network backpropagation approach", 2017, Research Journal of Biotechnology, Special Issue 2:157-166

[23] Kavitha, G., Kavitha, R., "An analysis to improve throughput of high-power hubs in mobile ad hoc network" , 2016, Journal of Chemical and Pharmaceutical Sciences, Vol-9, Issue-2: 361-363

[24] Kavitha, G., Kavitha, R., "Dipping interference to supplement throughput in MANET" , 2016, Journal of Chemical and Pharmaceutical Sciences, Vol-9, Issue-2: 357-360

[25] Michael, G., Chandrasekar, A.,'Leader election based malicious detection and response system in MANET using mechanism design approach", Journal of Chemical and Pharmaceutical Sciences(JCPS) Volume 9 Issue 2, April - June 2016.

[26] Michael, G., Chandrasekar, A.,'Modeling of detection of camouflaging worm using epidemic dynamic model and power spectral density", Journal of Chemical and Pharmaceutical Sciences(JCPS) Volume 9 Issue 2, April - June 2016.

[27] Pothumani, S., Sriram, M., Sridhar, J., Arul Selvan, G., Secure mobile agents communication on intranet,Journal of Chemical and Pharmaceutical Sciences, volume 9, Issue 3, Pg No S32-S35, 2016

[28] Pothumani, S., Sriram, M., Sridhar, Various schemes for database encryption-a survey, Journal of Chemical and Pharmaceutical Sciences, volume 9, Issue 3, Pg NoS103-S106, 2016

[29] Pothumani, S., Sriram, M., Sridhar, A novel economic framework for cloud and grid computing, Journal of Chemical and Pharmaceutical Sciences, volume 9, Issue 3, Pg No S29-S31, 2016

[30] Priya, N., Sridhar, J., Sriram, M. "Ecommerce Transaction Security Challenges and Prevention Methods- New Approach” 2016 ,Journal of Chemical and Pharmaceutical Sciences, JCPS Volume 9 Issue 3.page no:S66-S68 .

[31] Priya, N.,Sridhar,J.,Sriram, M."Vehicular cloud computing security issues and solutions" Journal of Chemical and Pharmaceutical Sciences(JCPS) Volume 9 Issue 2, April - June 2016

[32]

[33] Priya, N., Sridhar, J., Sriram, M. "Mobile large data storage security in cloud computing environment-a new approach" JCPS Volume 9 Issue 2. April - June 2016

[34] Anuradha.C, Khanna.V, "Improving network performance and security in WSN using decentralized hypothesis testing "Journal of Chemical and Pharmaceutical Sciences(JCPS) Volume 9 Issue 2, April - June 2016.

[35] Anuradha.C, Khanna.V, "A novel gsm based control for e-devices" Journal of Chemical and Pharmaceutical Sciences(JCPS) Volume 9 Issue 2, April - June 2016

[36] Anuradha.C, Khanna.V, "Secured privacy preserving sharing and data integration in mobile web environments " Journal of Chemical and Pharmaceutical Sciences(JCPS) Volume 9 Issue 2, April - June 2016.

[37] Sundarraj, B., Kaliyamurthie, K.P. Social network analysis for decisive the ultimate classification from the ensemble to boost accuracy rates 2016 International Journal of Pharmacy and Technology 8

[38] Sundarraj, B., Kaliyamurthie, K.P. A content-based spam filtering approach victimisation artificial neural networks 2016 International Journal of Pharmacy and Technology 83.

[39] Sundarraj, B., Kaliyamurthie, K.P. Remote sensing imaging for satellite image segmentation 2016 International Journal of Pharmacy and Technology 8 3.

[40] Sivaraman, K., Senthil, M. Intuitive driver proxy control using artificial intelligence 2016 International Journal of Pharmacy and Technology 8 .

[41] Sivaraman, K., Kaliyamurthie, K.P. Cloud computing in mobile technology 2016 Journal of Chemical and Pharmaceutical Sciences

$$
92 .
$$

[42] Sivaraman, K., Khanna, V. Implementation of an extension for browser to detect vulnerable elements on web pages and avoid click jacking 2016 Journal of Chemical and Pharmaceutical Sciences 92.

\section{AUTHOR PROFILE}

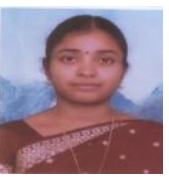

S.Pothumani, Department of CSE, Bharath Institute of Higher Education and Research, Chennai, Tamilnadu, India

K.Anita Davamani, Department of CSE, Bharath

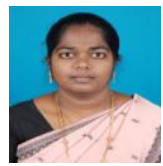
Institute of Higher Education and Research, Chennai, Tamilnadu, India.

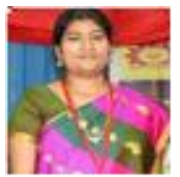

C.Anuradha, Department of CSE, Bharath Institute of Higher Education and Research, Chennai, Tamilnadu, India.

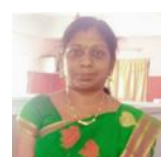

N.Priya, Assistant Professor, Department of Computer Science \& Engineering, Bharath Institute of Higher Education and Research, Chennai, India 